\title{
The Impact of Learning Cycle 5E On Children's Logical Thinking Ability and Symbolic Thinking
}

\author{
I Gusti Agung Diah Pradnya Antari, Mustaji Miftakhul Jannah \\ Universitas Negeri Surabaya \\ Surabaya, Indonesia \\ igadiah.unesa@gmail.com
}

\begin{abstract}
This study aims to determine the impact of learning cycle on children's logical thinking and symbolic thinking ability in Gugus Jempiring Kindergarten in North Denpasar. This research uses quantitative approach with quasi-experiment design. Seventy four children were selected as a sample in this research. Group B one as a group of experiments was given treatment of learning cycle and $B$ two as a control group. The data collection techniques is by using an instrument of logical thinking ability and symbolic thinking. The data were analyzed using non parametric statistics so that the Sign Test was done as well as Wilcoxon Matched Pairs Test.
\end{abstract}

Keywords-development, media production, video learning, learning outcomes

\section{INTRODUCTION}

Opportunities of providing the stimulation in early childhood is owned by the immediate environment of the child. As what [1] get said that teachers as the immediate environment of the child have the opportunity to provide the widest educational effect to the child to developing the child's abilities. Early child who gets a lot of stimulation or intensive educational stimulation from the environment in their golden years will grow into a positive person in accordance with the level of achievement of child development [2]. In addition, the stimulation of education from the child's environment will also develop the creativity of early childhood.

A close relationship between teachers and children will foster a comfortable climate for children to learn [3]. The existence of a close relationship between the child and the teacher is expected to be a bridge for teachers in providing learning that can stimulate the six aspects of child's development optimally [4]. One aspect of developments that is strongly influenced by the child's relationship with his environment is divided into three abilities namely learning and problem solving, logical thinking, and symbolic thinking [5]. When the child's cognitive development develops well then this can affect other developments as well. Therefore, the overall development of the child would be optimal.

Based on the observations in Gugus Jempiring Kindergarten in North Denpasar, it was found that the two thinking abilities in cognitive development have not developed as they should. This is because the teachers are still using conventional learning model that cannot stimulate logical thinking ability and symbolic thinking of group B children optimally. Children in group B need a learning model that can stimulate logical thinking and symbolic thinking of the child. Because the lessons given by the teacher still provide less experience and opportunities for children to explore. This made logical thinking ability and symbolic thinking in some of the children in group B have not developed optimally.

Differences in the characteristics of children who grow and develop in an advanced era should make teachers prepare different learning strategies, fun for children, and can make children build their own knowledge [6]. Therefore, through learning with many innovative activities the ability to think logically and symbolic thinking of the children can be stimulated. It is not a difficult thing if teachers are able to bring the atmosphere of play in every learning given in kindergarten, this is because play is an "obligation" of children. This is in accordance with Montessori's didactic principles in [7] states that all children learn by playing. Children learn through their process when playing. In short, play is a mean of children's learning.

Different learning processes from learning in general can be given by teacher in kindergarten [8]. Based on these problems, learning with Learning Cycle $5 \mathrm{E}$ model could be given to group B children in Gugus Jempiring Kindergarten in North Denpasar because this learning model is using student centered approach based on constructivistic approach [9]. As stated [10], that Learning Cycle 5E was different from the conventional model of learning common in kindergartens, because this learning model uses a constructivist learning model that discusses directly, mind-on and pedagogy-based observations. Learning Cycle 5E was developed into 5 phases: engagement, exploration, explanation, elaboration, and evaluation. According to [11] each phase of "E", sequentially provides learning experiences to learners in connecting prior knowledge with new concepts. The five phases of learning cycle is then better known as Learning Cycle 5E.

Learning Cycle $5 \mathrm{E}$ is very concerned about the experience and early knowledge of children and aims to provide opportunities for children to construct their knowledge and experience [12] . This learning model can improve understanding's concept of children. Therefore, in each phase of this learning model, the teacher as a facilitator can gives the child an opportunity to interact with other children, so that the child can build up their knowledge. From this description 
above, the Learning Cycle 5E model is expected to be able to stimulate the ability to think logically and think symbolically of the children group B Gugus Jempiring Kindergarten North Denpasar.

\section{METHOD}

The research design used in this study was quantitative approach. According to [13] the method of quantitative research is a method of research based on the philosophy of positivism, used in researching a population or a particular sample, in the data collection using research instruments, data analysis is statistical and has a purpose to test the hypothesis that has been set on research. The design of this study was a quasi-experiment using a control group and the sample was selected by non-random sampling technique [14]. This study was conducted to reveal the causal relationships involving the control group in addition to the experimental group in two kindergarten institutions. Because in each of the two institutions there were two groups of $\mathrm{B}$, therefore the researchers did not have to sort the two groups by random technique. The type of quasi-experiment research that used in this research was non-equivalent group design type which consists of experimental group and control group and the measurement is usually done with pretest and post-test [15].

The data collection techniques used in this study was the instrument of logical thinking ability and symbolic thinking. The validation test that used in this research is construct validity and content validity which calculated using SPSS22.00 for windows computing techniques. The validation test is performed to validate the instrument of logical thinking ability dan symbolic thinking. The test took several steps: (1) validity test by the expert (lecturer) and trial to the students by using correlation formula of product moment, (2) testing the reliability of the instrument outcomes through alpha cronbach. The data was analyzed using non parametric statistics so that the Sign Test is done as well as Wilcoxon Matched Pairs Test.

\section{RESULTS AND DISCUSSION}

The construct validity test in this research was done by requesting the help of two early childhood education experts (judgment experts) as appraisers. After conducting the construct validity, the instrument of logical thinking ability and symbolic thinking was calculated to 'content validity' with SPSS using correlation with product moment. The result of the instrument validation test of logical thinking ability and symbolic thinking from the validator were:

TABLE I. CONSTRUCT VALIDITY RESUlT

\begin{tabular}{|l|c|c|}
\hline \multicolumn{1}{|c|}{ Validation Sheet } & Percentage & Category \\
\hline $\begin{array}{l}\text { Learning equipment } \\
\text { instrument (early childhood } \\
\text { education expert) }\end{array}$ & $90 \%$ & $\begin{array}{c}\text { Advisable to use with no } \\
\text { revision }\end{array}$ \\
\hline $\begin{array}{l}\text { Learning equipment } \\
\text { instrument (early childhood } \\
\text { education expert) }\end{array}$ & $100 \%$ & $\begin{array}{c}\text { Advisable to use with no } \\
\text { revision }\end{array}$ \\
\hline
\end{tabular}


were performed. The following table provides hypothesis test results in this study:

TABLE V. THE RESULT OF HYPOTHESIS TEST

\begin{tabular}{|c|c|c|}
\hline Hipotesis & $\mathbf{Z}$ & Asymp. Sig 2 tailed $)$ \\
\hline $\mathrm{H} 1$ & -5.265 & 0.000 \\
\hline $\mathrm{H} 2$ & -5.277 & 0.000 \\
\hline
\end{tabular}

Based on table $\mathrm{V}$, it is known that the value of $\mathrm{Z}$ obtained in Wilcoxon Signed Ranks Test is -5.265 with $\mathrm{p}$ value (Asymp Sig 2 tailed) of 0,000 which means less than the critical limit of the study of 0.05 . Therefore, that the hypothesis decision is to accept $\mathrm{H} 1$ or there is significant difference in outcomes between the pretest and posttest groups. Therefore, it can be concluded that there is the influence of learning cycle $5 \mathrm{E}$ model to logical thinking ability in children Group B Gugus Jempiring Kindergarten North Denpasar.

From table $\mathrm{V}$, it is known that the value of $\mathrm{Z}$ obtained in Wilcoxon Signed Ranks Test of -5.277 with $p$ value (Asymp Sig 2 tailed) of 0.000. It means less than the critical limit of the study 0.05 , therefore the hypothesis decision is to receive $\mathrm{H} 2$. In other words, there is a significant difference in the outcomes between the pretest and posttest groups. Therefore, it can be concluded that there is the influence of learning cycle $5 \mathrm{E}$ model to the ability of symbolic thinking in children Group B Gugus Jempiring Kindergarten North Denpasar. Learning cycle $5 E$ model can be used as one model of learning to develop aspect of cognitive development, especially logical thinking ability and symbolic thinking of childred aged 5-6 years in kindergarten.

\section{CONCLUSION}

Based on the experiment result and discussion, it could be concluded that: (1) The learning cycle 5E model influences the logical thinking ability of children group B age 5-6 years Gugus Jempiring Kindergarten in North Denpasar. 2) The learning cycle $5 \mathrm{E}$ model influences the symbolic thinking ability of children of group B age 5-6 years Gugus Jempiring Kindergarten in North Denpasar. Learning cycle $5 E$ model can be used as one model of learning to develop aspect of cognitive development, especially logical thinking ability and symbolic thinking of childred aged 5-6 years in kindergarten.

\section{References}

[1] W. Gunarti dan A. Muis, Metode Pengembangan Perilaku dan Kemampuan Dasar Anak Usia Dini, Tangerang Selatan: Universitas Terbuka, 2015.

[2] M. Dalyono, Psikologi Pendidikan, Jakarta: Rineka Cipta, 2007.

[3] J. M. S. Desouza, "Conceptual Play and Science Inquiry: Using the 5E Instructional Model," Pedagogies: An International Journal, pp. 340-353, 2017.

[4] V. Carson, S. Hunter, N. Kuzic, S. Wiebe, J. Spence, A. Friedman, M. Tremblay, L. Slater and T. Hinkley, "Systematic Review of Physical Activity and Cognitive Development in Early Childhood," Science Medical Sport, pp. 578-3, 2016.

[5] K. P. d. Kebudayaan, Peraturan Menteri Pendidikan dan Kebudayaan RI Nomor 146 Tahun 2014 tentang Kurikulum 2013 Pendidikan Anak Usia Dini, Jakarta: Kemdikbud, 2015.

[6] M. Hannafin, J. Hill, S. Land dan E. Lee, "Student-Centered Open Learning Environments," Educational Communication and Technology, pp. 641-651, 2014.

[7] Suyadi dan M. Ulfah, Konsep Dasar PAUD, Bandung: Rosdakarya, 2013.

[8] J. Yoon dan J. A. Onchwari, "Teaching Young Children Science: Three Key Points," Early Chilhood Education, pp. 419-423, 2006.

[9] R. Bybee, J. Taylor, A. Gardner, P. Scooter, J. Powell, A. Brook dan N. Landes, "The BSCS 5E Instructional Model: Origins and Effectiveness," Science and Children, pp. 10-13, 2006.

[10] S. Balci, J. Cakiroglu dan C. Tekkaya, "Engangement, Exploration, Explanation, Elaboration and Evaluation (5E)," Biochemistry and Molecular Biology Education, pp. 199-203, 2006.

[11] M. Kurnaz dan M. Calik, "Using Different Conceptual Change Methods Embedded Within 5E Model: A Sample Teaching for Heat and Temperatur," Physics Teacher Education, pp. 1-25, 2008.

[12] D. Polly, A. Margerison dan J. A.Piel, "Kindergarten Teachers' Orientations to Teacher-Centered and Student-Centered Pedagogies and Their Influence on Their Students' Understanding of Addition," Research of Childhood Education, pp. 1-17, 2014

[13] Sugiyono, Metode Penelitian Pendidikan (Pendekatan Kuantitatif, Kualitatif dan R\&D), Bandung: Alfabeta, 2016

[14] Latipun, Psikologi Eksperimen, Malang: UMM Press, 2015.

[15] M. Jannah, Psikologi Eksperimen: Sebuah Pengantar, Surabaya: UNESA Press, 2016. 